
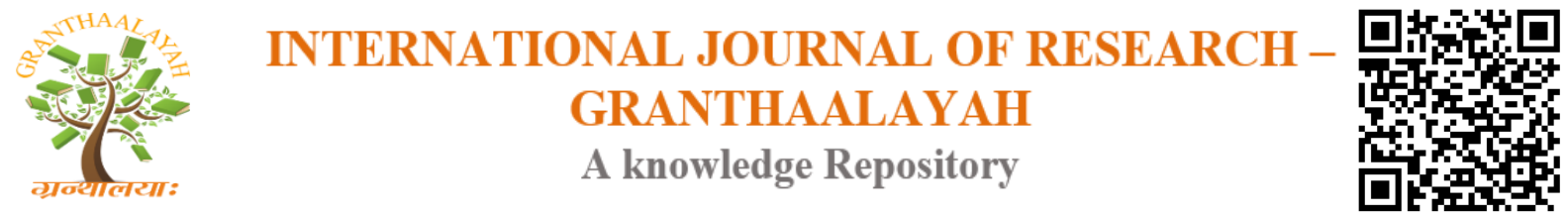

Social

\title{
EFFECT OF YOGIC PRACTICES ON FLEXIBILITY AMONG MENTALLY CHALLENGED CHILDREN
}

\author{
B.Srilakshmidevi ${ }^{1}$, Dr.V. Suseela ${ }^{2}$ \\ ${ }^{1}$ Research Scholar (Fulltime), Center for Yoga Studies, Annamalai University, India \\ ${ }^{2}$ Assistant Professor, Center for Yoga Studies, Annamalai University, India
}

\begin{abstract}
The aim of the study was to determine the effect of selected yogic practices on flexibility among Mentally Challenged Children.10 subjects were selected from 'Sathya Special School', puducherry selected students are in mild level. They were selected randomly and their age group was between 10 to 20 years. Single group formed. All are in Experimental group. The experimental group participated in yogic practice training and for 6 weeks. The data were collected in the beginning and at the end. The training schedule was prepared systemically. The significance was tested at 0.05 levels.
\end{abstract}

Keywords: Yoga; Mentally Challenged Children; Health; Happiness \& Adults.

Cite This Article: B.Srilakshmidevi, and Dr.V. Suseela. (2017). "EFFECT OF YOGIC PRACTICES ON FLEXIBILITY AMONG MENTALLY CHALLENGED CHILDREN." International Journal of Research - Granthaalayah, 5(7:SE), 56-60. https://doi.org/10.29121/granthaalayah.v5.i7(SE).2017.2123.

\section{Introduction}

Yoga is a scientific system of physical and mental practices that originated in India more than three thousand years ago. Its purpose is to help each one of us achieve our highest potential and to experience enduring health and happiness. With Yoga, we can extend our healthy, productive years far beyond the accepted norm and, at the same time, improve the quality of our lives. The branch of Yoga that forms the main focus of my teaching work with both adults and children is called Hatha Yoga.

Hatha Yoga begins by working with the body on a structural level, helping to align the vertebrae, increase flexibility, and strengthen muscles and connective tissue. At the same time, internal organs are toned and rejuvenated; the epidermal, digestive, lymphatic, cardiovascular, and pulmonary systems are purified of toxins and waste matter; the nervous and endocrine systems are balanced and toned; and brain cells are nourished and stimulated. The end result is increased mental clarity, emotional stability, and a greater sense of overall well-being. Yoga is a form of exercise based on the belief that the body and breath intimately connected with the mind. By 
controlling the breath and holding the body in steady poses, or asana, yoga creates harmony. Yoga is means of balancing and harmonizing the body, mind and emotion and is a tool that allows us to withdraw from the chaos of the world and find a quite space within.

Increasing the range of motion creates good postures and develops proficiency performance in everyday activities increasing the length of life and overall health of the individual.

\section{Objectives of the Study}

The aim of the study was to find out the Effect of yogic practices on Flexibility among mentally challenged students.

\section{Methodology}

For the purpose of the study 10 students were selected randomly from Satya Special School and their age group was between 10- 20 years were selected, with their parent and teacher consent. Single group formed. All are in Experimental Group. The experimental group participated in yogic practices for 6 week there is no control group. The data were collected in the beginning and at the end. The training schedule was prepared systemically. The significance was tested at 0.05 levels.

\section{Administration of test}

Flexibility

Equipment:

Flexibility was measured with V-Sit and Reach test.

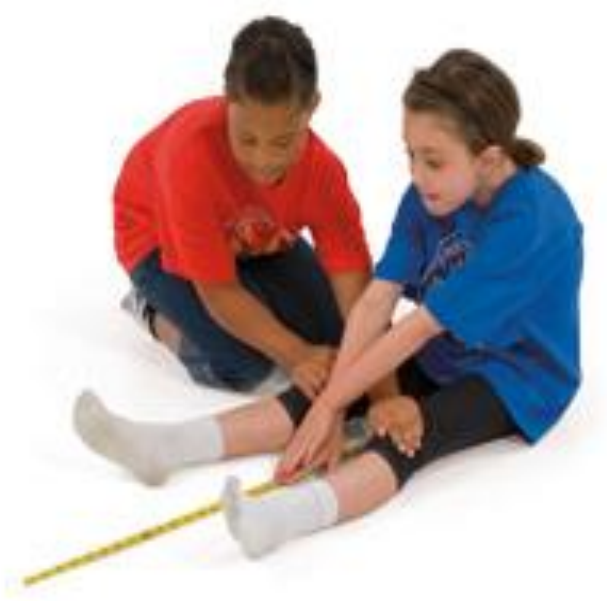

\section{Description:}

The subject responses are scored. In addition, the results are tabulated. The flexibility of the pre and post test scores of experimental group have been analyzed and presented in the below.The table shows the scores of the v-sit and reach test.

\section{scoring}

The total score for a subject ranges from11 to 23. The individual interpretation can be done through V-sit and reach flexibility Norms and proceeds and percentiles (\%ile). 


\section{Interpretation}

Female:

Age : Under 25

$>14$ very poor

15-16 poor

17-19 average

20-21 above average

22 good

$<23$ excellent
Male:

Age : under 25

$>11$ very poor

12-13 poor

14-17 average

18-19 above average

21 good

$<22$ excellent

\section{Training Format}

Training protocol: The experimental group under went training that consist of preparatory practice and loosening practice and seven asana practice session, in a week 5 days for 6 weeks. In the morning, yogic training administrated from Monday to Friday respectively.

\begin{tabular}{|l|l|}
\hline Name of the asana & Duration of asana \\
\hline $\begin{array}{l}\text { ASANAS } \\
\text { Strecting practices }\end{array}$ & 5 minutes \\
\hline Loosening practices & 5 minutes \\
\hline Surynamaskara & 5 rounds \\
\hline $\begin{array}{l}\text { Padmasana } \\
\text { Pawanamukthasana }\end{array}$ & 2 times in each, 4 minutes \\
\hline $\begin{array}{l}\text { Trikonasana } \\
\text { Padahastasana }\end{array}$ & 4 times in each, 6 minutes \\
\hline $\begin{array}{l}\text { Pachimothasana } \\
\text { Makrasana }\end{array}$ & 4 times in each, 8 min \\
\hline Kabalapathi, bastrika & 5 minutes \\
\hline Deep relaxation technique & 20 minutes \\
\hline
\end{tabular}

\section{Experimental Design and Statistical Procedure}

The experimental group design used in this study was random group design involved ten subjects were included both male and female. Analysis of Variance (ANOVA) was used for computing. Analysis of variance on flexibility of yogic practice group through $\mathrm{V}$-sit and reach test is tabulated in table 1 and graphically represented in figure-1.

Mean and standard deviations on flexibility of mentally challenged children

\begin{tabular}{|c|l|l|l|l|l|l|c|}
\hline Variable & $\begin{array}{c}\text { Testing } \\
\text { Conditions }\end{array}$ & \multicolumn{1}{|c|}{ Mean } & N & $\begin{array}{c}\text { Std. } \\
\text { Deviation }\end{array}$ & \multicolumn{1}{|c|}{ MD } & \multicolumn{1}{c|}{$\boldsymbol{T}$} & Df \\
\hline Flexibility & Pre & 18.90 & 10 & 2.33095 & -1.90 & $\begin{array}{l}-4.670 \\
(p=0.001)\end{array}$ & 9 \\
\hline
\end{tabular}




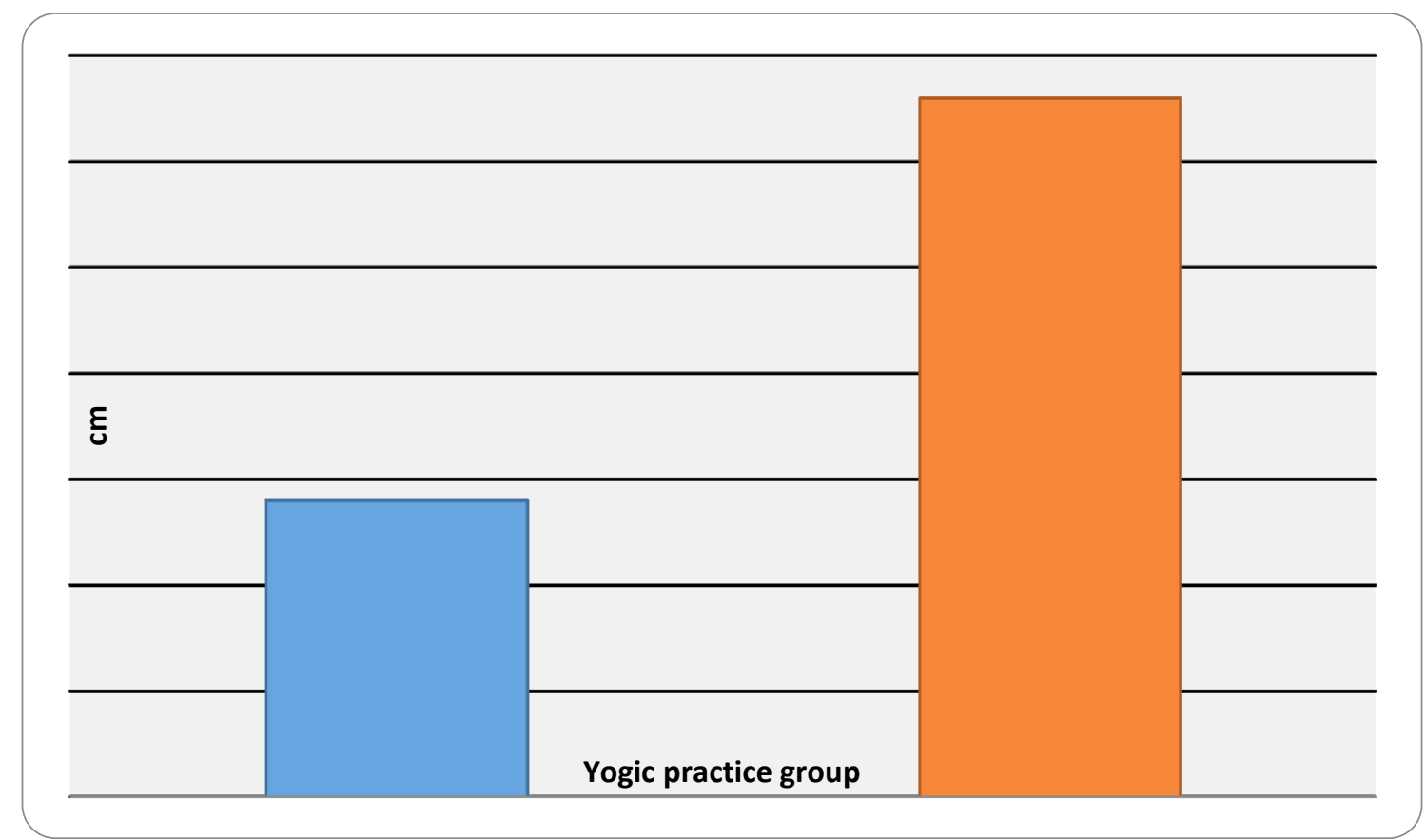

Figure 1: Changes in flexibility from pre to post on mentally challenged students

\section{Changes in flexibility from pre to post on mentally challenged students}

The flexibility of the pre and post test scores of experimental group have been analyzed and presented in the below Table I.

It is clear from Table 1 that there is a significant improvement in mentally challenged children on flexibility, as $t(d f 9)=4.670, p<0.05$. It also clearly shows that flexibility increased from 18.90 to $20.80 \mathrm{~cm}$ through yogic practices and recorded $10.05 \%$ increase (MD $-1.90 \mathrm{~cm}$ ). It is interpreted that yogic practice showed significant increase (10.05\%) in flexibility for mentally challenged children.

\section{Conclusion}

The result of the study shows there is significant difference between yogic practice group on flexibility. Moreover, the result of the study shows that there is significant improvement in flexibility compared to pre -test.

\section{References}

[1] AraujoCGS.Flexitest: an innovative flexibility assessment method. Champaign: Human Kinetics; 2003.205p.Boucher S. Yoga for Cancer. Yoga J. 2007.Retrievedxsfrom http://www.yogajournal.com/health/126

[2] Jayachandran and Ananthanarayanan T.V.-Two case studies of asana therapy in the management of mental retardation. Paper presented at the National, Symposium 'Yoga, Brain and consciousness NIMHANS, Bangalore,India. (1982)Jan. PP. 1-2.

[3] Nagendra H.R. and Nagarathna R.-Initial studies for Yoga Therapy for the Mentally Retarded. Vivekananda YOCTAS, (1984) Report No.VKYOCTAS/BN/014184. 
[4] Rajyalakshmi- Effect of certain Yogasanas on Mentally Retarded children, Mimeograph of the Indian Institute of allied sciences, Tirupathi (1979).

[5] Shogren, K. A., \&Plotner, A. J. (2012). Transition planning for Students with intellectual disability, autism, or other disabilities: Data from the National Longitudinal Transition Study-2. Intellectual and Developmental Disabilities, 50, 16-30.

[6] Uma K, Nagendra HR, Nagarathna R, et al. The integrated approach of yoga: a therapeutic tool for mentally retarded children: one-year controlled study. J Ment Defic Res. 1989; 33:415-421. 